\title{
Pengembangan Media Poster dengan Konteks Covid-19 untuk Memperkenalkan Kegunaan Statistika
}

\author{
Mira Nurhayati ${ }^{1}$, Ego $^{2}$, Friska Mahatri ${ }^{3}$, Zulkardi $^{4}$, Meryansumayeka* \\ ${ }^{1,2,3}$ Universitas Sriwijaya,Indralaya \\ ${ }^{4,5}$ Universitas Sriwijaya,Palembang \\ Penulis Korespondensi: meryansumayeka@fkip.unsri.ac.id
}

\begin{abstract}
The study was intended to develop a media poster with the context of covid-19 to introduce statistic uses. With the poster's media development it is hoped to help educators to give math lessons with the help of the media poster so that the planned learning goals can be achieved. The type of research methods used is development based on research research and development (R\&D) methods. The study centers on poster learning media on statistika subjects with the context of covid-19. In this study and development the author uses only five steps from the ten $r \& d$ method research steps of potential and problem, product design, design validation, design revision and product testing. Based on the research process carried out, it is found that learning with a media poster in the context of covid-19 on statistika materials can attract the attention and interest of students in mathematical learning.
\end{abstract}

Keywords: Covid-19, developmen, media poster, statistics

Abstrak: Penelitian ini bertujuan untuk mengembangkan media poster dengan konteks Covid-19 untuk memperkenalkan kegunaan statistika. Melalui pengembangan media poster ini diharapkan dapat membantu para pendidik untuk dapat memberikan pelajaran matematika dengan bantuan media poster agar tujuan pembelajaran yang telah direncanakan dapat tercapai. Jenis metode penelitian yang digunakan adalah pengembangan dengan berdasar pada metode penelitian Research and Development (R\&D). Penelitian ini memusatkan pengembangan media pembelajaran poster pada mata pelajaran statistika dengan konteks Covid-19. Pada penelitian dan pengembangan ini penulis hanya menggunakan lima langkah dari sepuluh langkah-langkah penelitian metode R\&D yaitu potensi dan masalah, desain produk, validasi desain, revisi desain dan uji coba produk. Berdasarkan proses penelitian yang dilakukan diperoleh bahwa pembelajaran dengan media poster dengan konteks Covid-19 pada materi statistika dapat menarik perhatian dan minat siswa dalam pembelajaran matematika.

Kata kunci: Covid-19, media poster, pengembangan, statistika

\section{PENDAHULUAN}

Pembelajaran merupakan usaha-usaha yang telah direncanakan yang menggunakan sumber-sumber belajar agar dapat terjadinya proses belajar pada diri seseorang (Sadirman \& dkk, 1996). Hal ini sama seperti yang tertuang dalam (Undang - Undang Nomor 20 mengenai Sistem Pendidikan Nasional, 2003) yang menyampaikan tentang pembelajaran merupakan suatu proses interaksi yang terjadi antara pendidik dan peserta didik pada suatu lingkungan belajar, sehingga suatu kegiatan dapat dikatakan pembelajaran apabila terjadinya interaksi antara peserta didik dengan pendidik yang telah direncanakan.

Saat ini, pembelajaran yang sedang berlangsung di Indonesia mengalami perubahan disebabkan oleh pandemi Covid-19 yang melanda seluruh dunia. Virus Covid-19 mulai masuk ke Indonesia sekitar bulan Maret 2020. Hingga saat ini menurut data pada (Covid-19, hal. data penyebaran Covud-19)menyatakan bahwa 
kasus yang telah terkonfirmasi hingga 29 April 2021 sebanyak 1.662 .868 jiwa. Hal ini mengakibatkan pembelajaran yang seharusnya diadakan di sekolah, dialihkan di rumah dengan cara pembelajaran jarak jauh. Hal ini tertuang dalam (Peraturan Menteri Pendidikan dan Kebudayaan Nomor 24 tentang Penyelenggaraan Pendidikan Jarak Jauh , 2012) yang menyampaikan bahwa pembelajaran untuk saat pandemi ini dilakukan secara daring. Akibatnya, para pendidik pun berpikir mengenai bagaimana cara agar materi pembelajaran tetap tersampikan walaupun tidak bertemu secara langsung di sekolah. Salah satu caranya yaitu dengan menyampaikan materi melalui media pembelajaran.

Media pembelajaran merupakan salah satu komponen yang cukup penting dari proses pembelajaran (Falahudin, 2014). Media pembelajaran adalah suatu perantara berupa bahan,alat, atau teknik yang digunakan untuk menunjang proses pembelajaran (Netriwati \& Lena, 2017). Media pembelajaran juag merupakan suatu wahana dalam menyampaikan informasi yang berkaiatan dengan pembelajara kepada peserta didik (Amir, 2016). Dengan adanya penggunaan media pembelajaran dapat membangkitkan minat dan motivasi peserta didik dalam pembeljaran termasuk matematika (Falahudin, 2014).

Menurut (Netriwati \& Lena, 2017), media pembelajaran memiliki beberapa kegunaan seperti dapat membantu: (1) menarik perhatian siswa terhadap materi pembelajaran (2)mengatasi perbedaan pengalaman belajar dan memberikan pengalaman yang baru (3)perkembangan pemikiran siswa (4)mengurangi adanya verbalisme.

Pada buku (Netriwati \& Lena, 2017) yang dikutip dari (Djamarah \& dkk, 2006) membagi media pembelajaran berdasarkan jenisnya menjadi tiga bagian. Pertama, auditif yaitu media pembelajaran yang dapat didengarkan atau berfokus pada suara seperti radio,rekoorder,dan lainnya. Kedua, visual yaitu media pembelajaran yang dapat dilihat atau mengandalkan indera penglihatan seperti gambar,foto,poster,dan sebagainya. Lalu yang ketiga, audio visual yaitu media pembelajaran yang dapat dilihat dan didengarkan seperti video interaktif dan lainnya.

Pada penelitian (Kusumawardani, Siswanto, \& Purnamasari, 2018) menyatakan bahwa penggunaan media pembelajaran berupa poster atau gambar efektif digunakan dalam proses pembelajaran. Hal ini selaras dengan penelitian (Amir, 2016) yaitu media pembelajaran berupa gambar atau poster dapat memperlancar proses pembelajaran matematika. Materi pembelajaran yang dapat dibuat dalam media poster dapat beraneka ragam sesuai dengan kebutuhan salah satunya kita dapat menggunakan media poster untuk mengenalkan materi statistika pada tingkat SMP. Penggunaan media poster dalam pembelajaran matematika ini juga didukung oleh sebuah wadah yang mengadakan pameran poster matematika seluruh dunia(Maulidyawati \& Irham, 2020).

Selain itu, media poster yang telah dibuat dapat diikutsertakan dalam pameran internasional melalui website IDM314 yaitu https://www.idm314.org/. IDM314 merupakan sebuah website yang terdiri dari seluruh negara di dunia yang bertujuan 
untuk memperingati Hari Matematika Internasional yang jatuh pada tanggal 14 Maret atau yang lebih dikenal dengan nama Pi Day (Union). Melalui IDM314 seluruh negara di dunia dapat memperingati Hari Matematika Internasional secara bersama-sama. Ada beberapa rangkaian dalam peringatan hari tersebut salah satunya adalah lomba poster matematika yang memiliki tema yang berbeda setiap tahunnya. Jadi, media poster bukan saja dapat digunakan untuk menunjang pembelajaran tetapi juga dapat diikutsertakan dalam pameran untuk memperingati Hari Matematika Internasional.

Berdasarkan penelitian(Purnomo, Dalyono, \& Handayani, 2018), perbedaanya pada penelitian ini adalah pada penelitian yang dilakukan oleh (Purnomo, Dalyono, \&Handayani, 2018) adalah pengembangan media pembelajaran statistika sedangkan pada penelitian ini merupakan pengembangan media poster menggunakan konteks Covid-19 untuk mengenalkan Statistika pada peserta didik.Dengan demikian, tujuan diadakannya penelitian ini adalah untuk mengetahui bagaimana proses pengembangan media poster dengan konteks Covid-19 untuk mengenalkan Statistika pada peserta didik.

\section{METODE}

Metode yang digunakan pada penelitian ini menggunakan jenis metode penelitian dan pengembangan yang berdasar pada metode penelitian Research and Development (R\&D). Menurut Sugiyono (2015), Research and Development adalah metode penelitian yang digunakan untuk menghasilkan suatu produk dan menguji keefektifan produk tersebut. Fokus penelitian ini adalah mengembangkan media pembelajaran poster tentang statistika dengan konteks Covid-19. Dari segi penelitian ( Dityatulloh \& santosa, 2018), langkah-langkahpenelitian dan pengembangan dibagi menjadi sepuluh tahap yaitu potensi dan masalah, pengumpulan data, desain produk, validasi desain, revisi desain, uji coba produk, revisi produk, uji coba pemakaian, revisi produk dan produksi massal (Sugiyono, 2015).

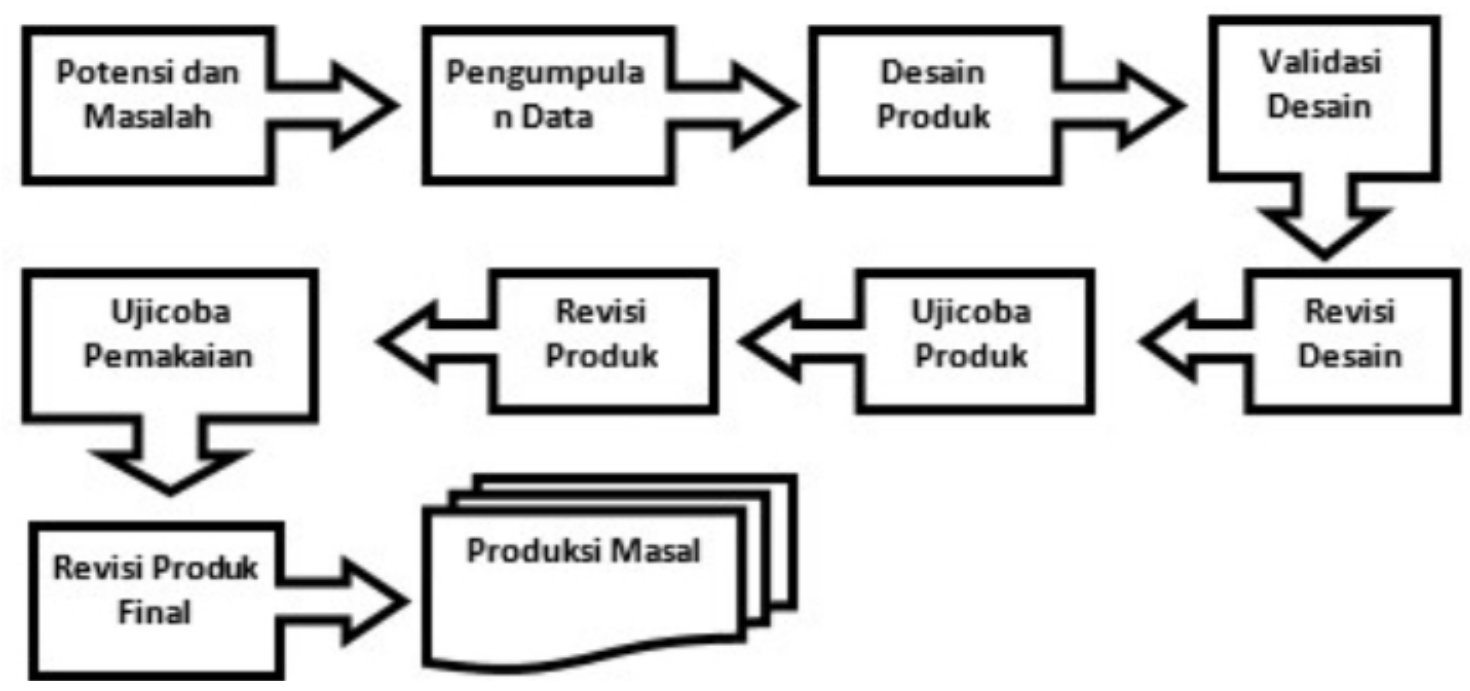

Gambar 1. Langkah-langkah Penelitian Metode R\&D 
Dalam penelitian dan pengembangan ini penulis hanya menggunakan limadari sepuluh langkahpenelitian metode R\&D yaitu potensi dan masalah,desain produk, validasi desain, revisi desain dan uji coba produk. Teknis analisis data yang digunakan dalam penelitian ini divalidasi secara kualitatif, dilakukandengan dosen mata kuliah Media Pembelajaran dan juga menyebarkannya lewat media sosial.

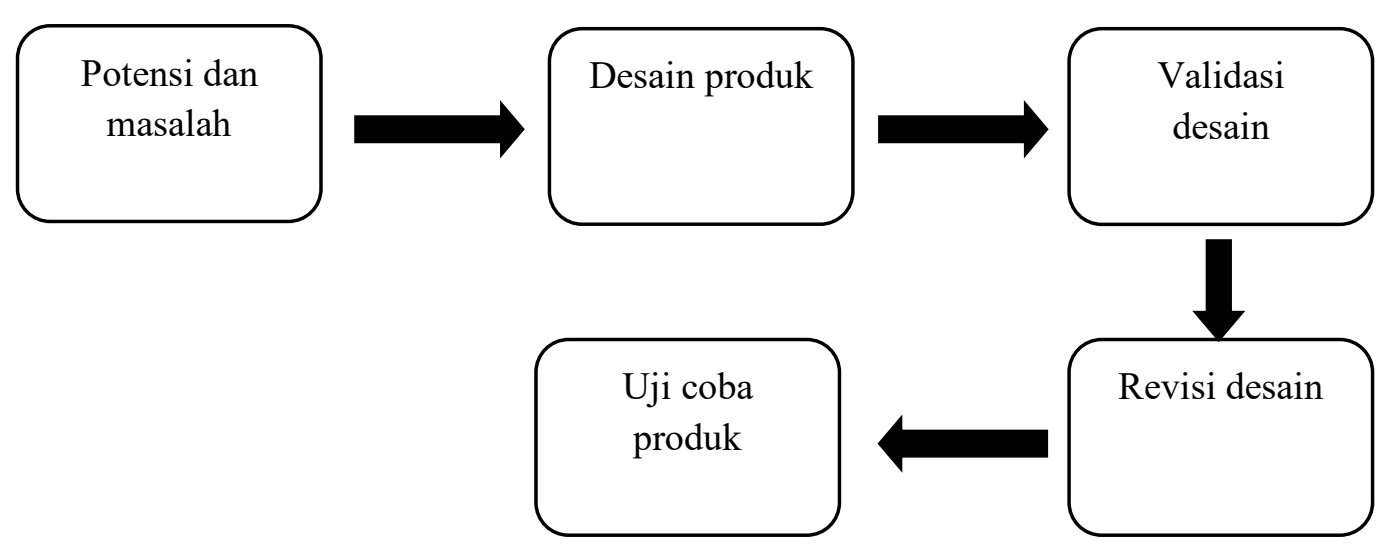

Gambar 2. Desain Langkah-Langkah oleh Peneliti

Langkah - langkah yang digunakan penulis yaitu 5 langkah. Pertama potensi dan masalah dilakukan dengan diskusi kelompok. Selanjutnya desain produk dilakukan dengan diskusi kelompok. Selanjutnya validasi desain yaitu dengan validasi kualitatif yang dilakukan dengan dosen mata kuliah Media Pembelajaran dan juga menyebarkannya lewat sosial media. Selanjutnya revisi desain dilakukan dengan diskusi kelompok. Terakhir uji coba produk diikutsertakan dalam pameran yang diadakan oleh IDM 314.

\section{HASIL DAN PEMBAHASAN}

Kasus Covid-19 pertama kali diketahui menginfeksi masyarakat Indonesia pada 2 Maret 2020 (Kemkes, 2020). Menurut Satuan Tugas Penanganan Covid-19 sampai pada 17 April 2021 terdapat 1,6 juta kasus Covid-19 yang terjadi di Indonesia. Banyaknya masyarakat yang terpapar Covid-19 membuat pemerintah mengeluarkan Surat Edaran No. 4 Tahun 2020 tentang peraturan yang mengintruksikan kepada masyarakat supaya menerapkan Physical Distancing atau memberi jarak dengan orang lain sejauh satu meter dan menghindari keramaian (Covid-19, 2020).

Pembelajaran jarak jauh yang dilakukan selama masa pandemi Covid-19, menuntut seluruh civitas akademika untuk beradaptasi dalam melakukan kegiatan belajar mengajar. Berbagai hal dilakukan untuk memberikan pendidikan yang baik. Penggunaan platform juga dilakukan untuk membuat suatu media pembelajaran yang menarik bagi para pelajar (Rusman, 2019). Disamping menarik juga dapat dibagikan kepada siswa walaupun guru dan siswa tidak berada di ruangan yang sama. 
Salah satu media yang menarik dan mudah dibagikan ke semua siswa meski berjauhan ialah media poster. Media poster yang baik dikembangkan sesuai dengan konteks kejadian yang sedang terjadi di daerah yang akan dibagikan media poster tersebut. Hal ini dilakukan sebagai upaya untuk membuat poster menjadi menarik. Kejadian yang sekarang menjadi perbincangan dunia ialah pandemi Covid-19. Hal matematis yang sangat melekat dengan penyebaran Covid-19 ialah penyajian data yang begitu penting dalam mengambil setiap kebijakan penanganan Covid-19. Data penyebaran Covid-19 dapat kita lihat melalui https://covid19.go.id/. Berikut contoh data yang kita dapat melalui website https://covid19.go.id/ tersebut.
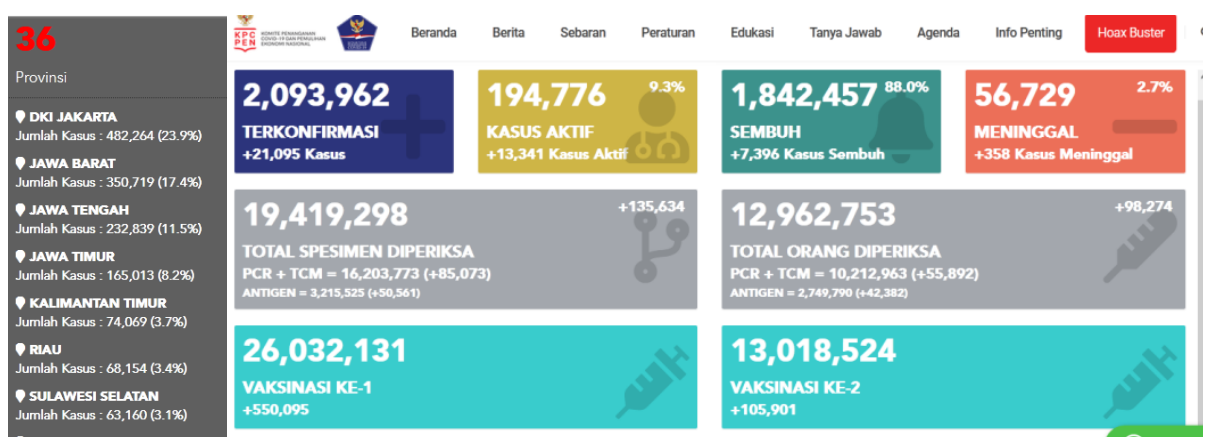

Gambar 3. Data Penyebaran Covid-19

Media poster ini dibuat dengan mengkombinasikan materi kegunaan statistika dengan konteks Covid-19. Hal ini dirasa sangat tepat untuk mengajarkan pentingnya statistika dalam kehidupan. Media poster yang dikembangkan menggunakan salah satu aplikasi desain yang umum digunakan. Adapun langkah-langkah dalam pembuatan media poster ini sebagai berikut.

(1) Buka aplikasi desain yang akan digunakan, dalam penelitian kali ini aplikasi yang digunakan adalah corel draw.

(2) Atur canvas berukuran A4.

(3) Buatlah setengah lingkaran yang diletakkan dibagian bawah canvas A4 tersebut.

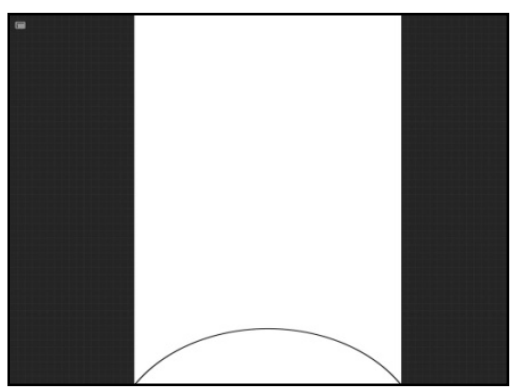

Gambar 4. Membuat Setengah Lingkaran

(4) Aktifkan mode pencerminan pada aplikasi desain.

(5) Buat gelombang pada salah satu sisi, cukup satu karena dengan mode pencerminan sisi yang lain juga akan tergambar. 


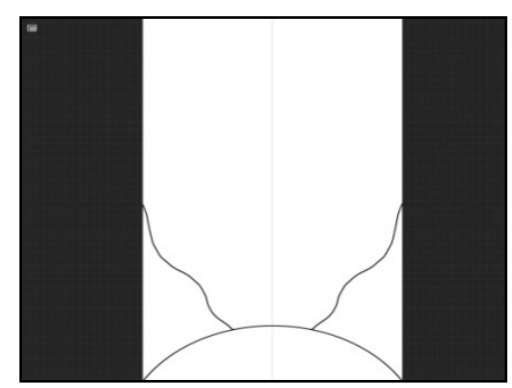

Gambar 5. Membuat Gelombang pada Kedua Sisi

(6) Matikan mode pencerminan.

(7) Warnai bagian atas canvas yang telah dibatasi dengan gelombang.

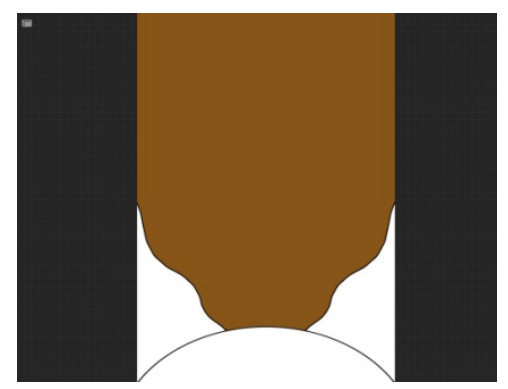

Gambar 6. Mewarnai Bagian Atas

(8) Buatlah lingkaran ditengah kanvas.

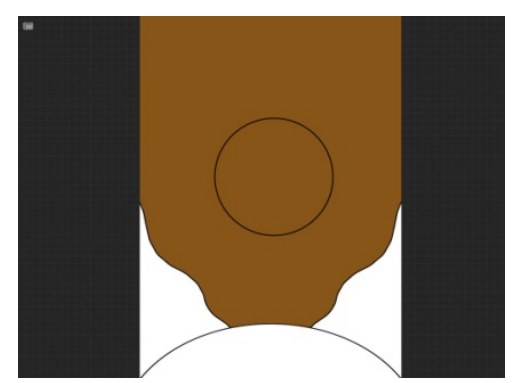

Gambar 7. Membuat Lingkaran

(9) Potong warna yang telah diberikan pada langkah (7) dengan lingkaran tersebut

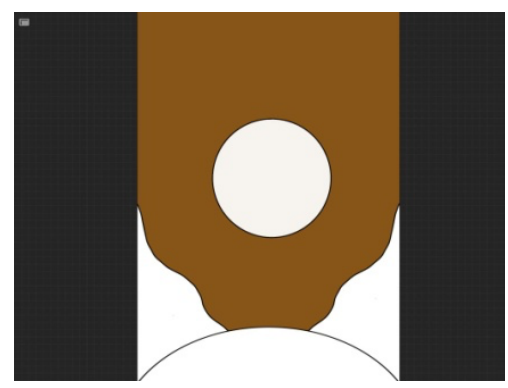

Gambar 8. Menghapus Warna Sesuai Lingkaran 
(10) Siapkan vektor seperti rumah sakit, vaksin, virus, dan vektor diagram
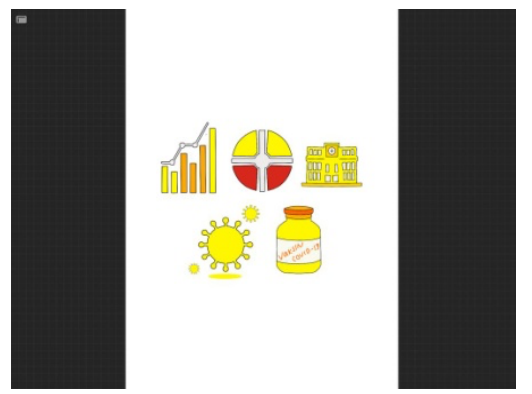

Gambar 9. Vektor yang Disiapkan

(11) Susun vektor pada langkah (10) ditepi lingkaran pada langkah (8)

(12) Lalu buat tanda panah mengelilingi lingkaran pada langkah (8) untuk menggabungkan tiap vektor sehingga seperti daur ulang yang kontinue

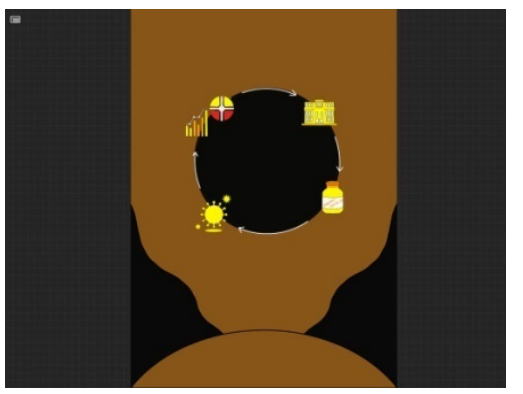

Gambar 10. Hasil Akhir

Pewarnaan yang diteterapkan dalam pengembangan media poster ini menggunakan tone earth dengan feel ruang angkasa dan vektor berwarna kuning. Warna kuning pada vektor terisnpirasi dari warna matahari yang menjadi pusat tata surya di ruang angkasa.

Setelah media poster dibuat maka selanjutnya dilakukan uji kelayakan model dengan cara validasi kualitatif yang dilakukan dengan dosen mata kuliah Media Pembelajaran dan juga menyebarkannya lewat sosial media. Penyebaran di sosial media dilakukan untuk mendapatkan lebih banyak masukan dari para milenial yang dalam hal ini kebanyakan adalah mahasiswa S1 Pendidikan Matematika. Melalui instagram dengan fitur pemberian masukan,kami melakukan validasi pada publik dengan menyebarkannya. Pertanyaan yang kami berikan melalui fitur pemberian masukan pada Instagram yaitu "Tolong berikan saran mengenai poster yang telah kami susun baik dari penampilan maupun dari isinya?”. 

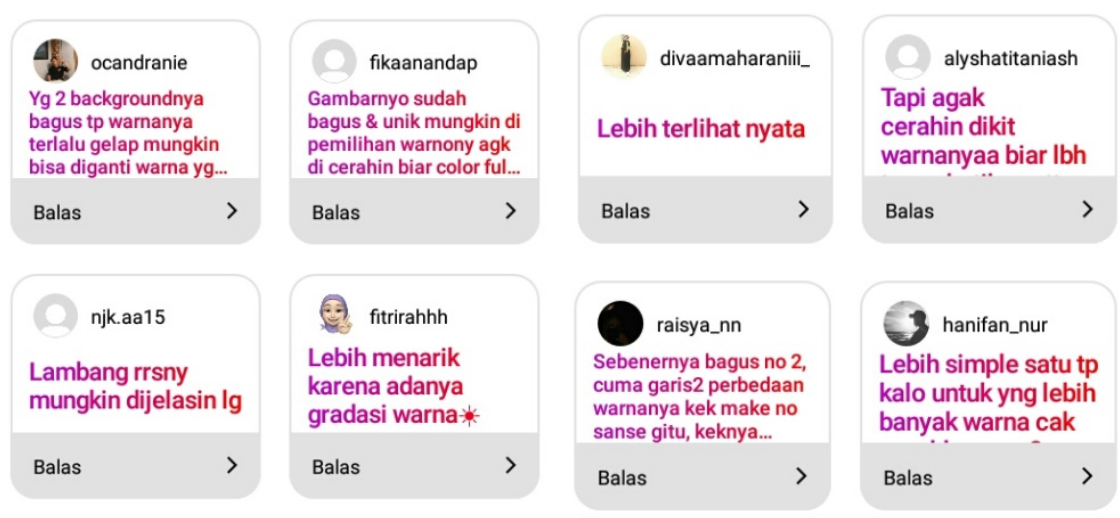

Gambar 11. Masukan dari Sosial Media

Proses validasi dengan dosen dilakukan secara langsung melalui Zoom Meeting. Dosen memberikan beberapa saran untuk poster yang telah kami susun. Saran yang diberikan oleh dosen yaitu pada tabel berikut.

Tabel 1. Saran dari Dosen pada Saat Proses Validasi

\begin{tabular}{ll}
\hline No & Saran \\
\hline 1 & Tambahkan judul pada poster \\
2 & Sesuiakan dengan tema dari website IDM314 \\
3 & Perhatikan lagi mengenai isi atau pesan yang ingin disampaikan \\
4 & Materi yang disampaikan sudah baik \\
\hline
\end{tabular}

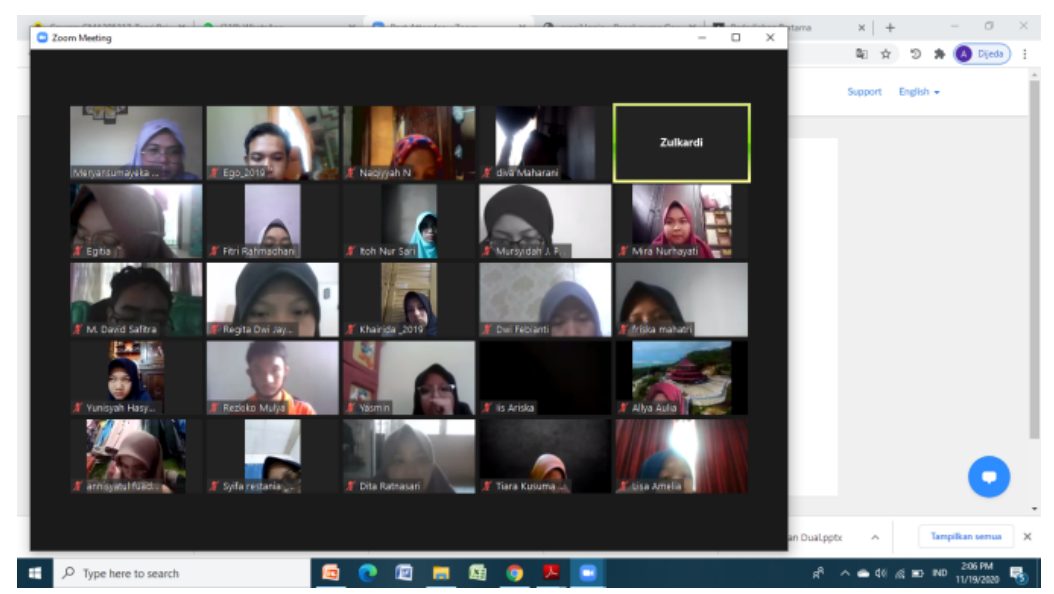

Gambar 12.Validasi Kualitatif Bersama Dosen

Setelah dilakukan validasi kualitatif dengan dosen Mata Kuliah Media Pembelajaran dan melalui sosial media yaitu Instagram didapatkan beberapa saran untuk media poster yang telah dikembangkan. Saran yang didapatkan dijadikan masukan untuk revisi media poster awal. Hasil revisi desain dapat disajikan sebagai berikut.

Beberapa saran di atas adalah mengenai desain produk, sedangkan untuk konten ataup isi dari posternya tidak ada saran yang menyatakan diperlukannya diperbaikan. 
Karena untuk konten materi sendiri telah dipahami. Konten statistika yang ditunjukkan ialah gambar grafik batang yang disajikan pada poster. Melalui tampilan grafik batang seperti itu bertujuan untuk menunjukkan bahwa data covid dapat disajikan dalam diagram batang yang kemudian dijadikan acuan untuk mengambil kebijakan guna memutus mata rantai penyebaran Covid-19. Gambar produk setelah diperbaiki dari beberapa saran tersebut.

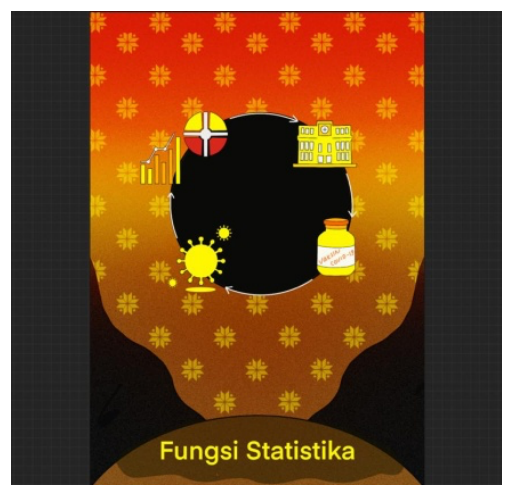

Gambar 13. Media Poster Setelah Revisi

Proses pengembangan poster dilanjutkan dengan melakukan uji coba poster yang telah direvisi. Tahap uji coba produk pada penelitian ini yaitu dengan mengikutsertakan media poster dalam pameran yang diadakan oleh IDM 314. Pada tahun 2021, tema yang diadakan oleh IDM314 adalah Mathematics for a Better World. Setelah media poster dibuat dan revisi, kami mensubmitkannya ke website IDM314 untuk diikutsertakan. Dalam proses mensubmitkan media poster kita cukup dengan mengakses link berikut yaitu https://www.idm314.org/ maka kita akan masuk ke website IDM314.

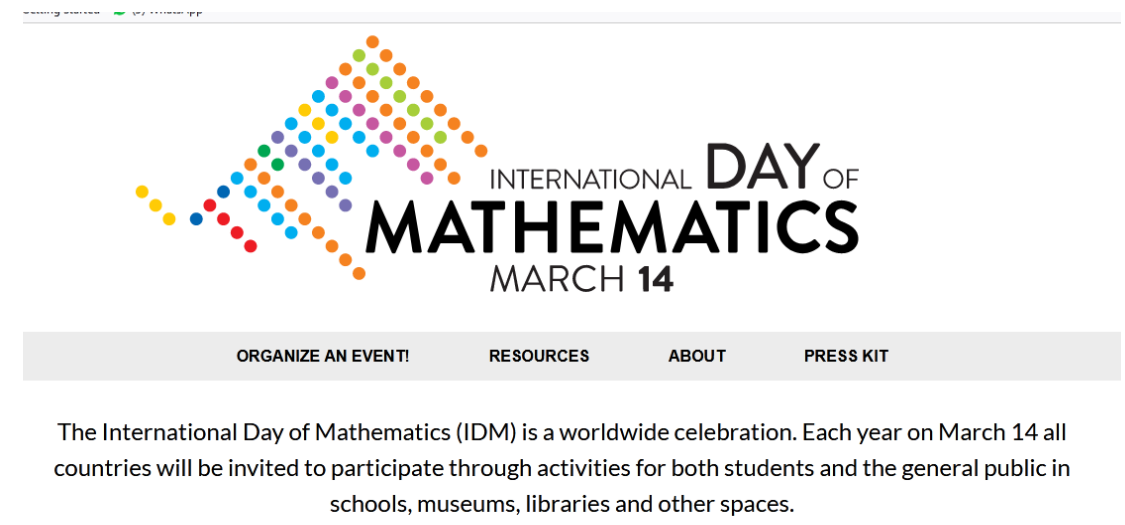

Gambar 14. Tampilan awal IDM314

Kemudian untuk mensubmitkan media poster kita dapat memilih seperti gambar dibawah ini. Selain itu, kita dapat melihat syarat-syarat khusus mengenai poster yang memenuhi syarat dari IDM314. 
arawıngs combıned witn matnematıcs to neip you communicate the idea to people all over the globe. You can use all sorts of mathematical elements, for example:

- Formulas and mathematical operations.

- Geometric shapes.

- Charts and plots.

- Graphs.

- Tessellations.

- Fractals.

Submit it before the end of March 1, 2021.

Submit your poster

\section{TECHNICAL DETAILS}

Format: One JPG, PNG, or PDF file (up to $5 \mathrm{MB})$.

Size: A $1754 \times 2480$ pixel image. If you're an image PRO, send an image file in A3 format

Gambar 15. Tampilan untuk Mensubmitkan Media Poster

Dengan demikian, untuk tahap uji coba produk media poster dalam penelitian ini dengan mengikutsertakannya dalam pameran internasional untuk memperingati Hari Matematika Internasional melalui IDM314. Kemudian kita juga dapat melihat beberapa media poster dari seluruh negara yang berpartisipasi. 


MATHEMMATICS ORGANIZE AN EVENTI RESOURCES ABOUT PRESS KIT

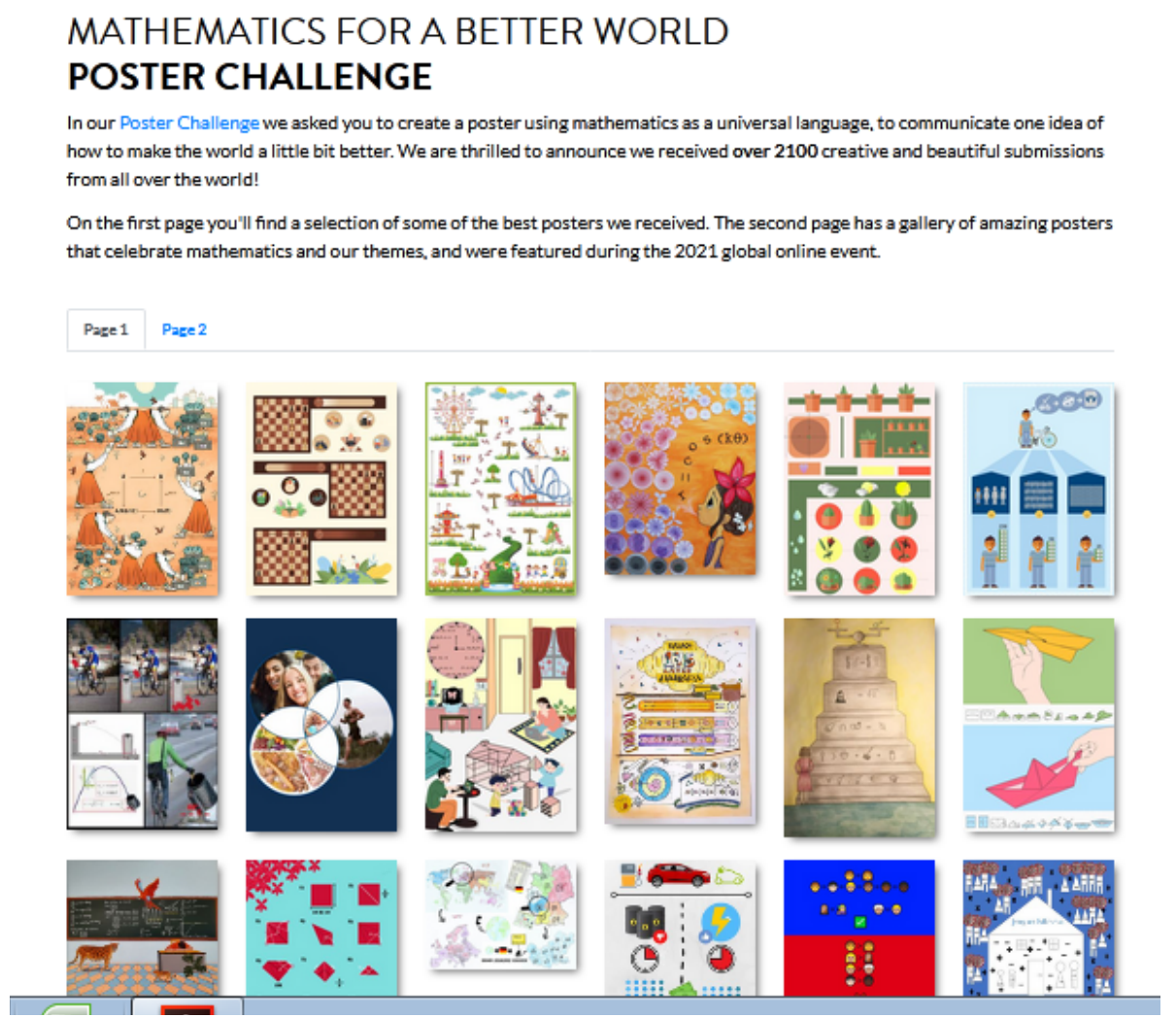

Gambar 16. Media Poster dari Berbagai Negara

\section{SIMPULAN DAN SARAN}

Berdasarkan proses penelitian yang dilakukan diperoleh bahwa pembelajaran dengan media poster dengan konteks Covid-19 pada materi statistika dapat lebih menarik perhatian dan minat siswa dalam pembelajaran matematika serta dapat diikutisertakan pameran internasional untuk memperingati Hari Matematika Internasional melalui IDM314.

Berdasarkan hasil penelitian, terdapat beberapa saran yaitu (1) untuk guru, diharapkan guru lebih sering menggunakan poster untuk proses pembelajaran, serta dalam pembuatan poster agar lebih baik, kreatif dan disesuaikan dengan tujuan pembelajaran yang direncanakan. (2) untuk penelitian selanjutnya, jenis penelitian yang telah dilakukan merupakan penelitian pengembangan dengan tujuan menghasilkan produk yang valid dan praktis serta dapat menarik perhatian dan minat siswa. Kedepannya , bagi peneliti selanjutnya diharapkan dapat menggunakan media - media lain yang lebih inovatif. 


\section{DAFTAR PUSTAKA}

Amir, A. (2016). Penggunaan Media Gambar dalam Pembelajaran Matematika. Jurnal Eksakta, 35-39.

Covid-19, D. J. (2020). Pedoman Pencegahan dan Pengendalian Coronavirus Disease. Jakarta: Kementrian Kesehatan Republik Indonesia.

Covid-19, S. T. (t.thn.). Dipetik April 30, 2021, dari https://covid19.go.id/

Dityatulloh, S. R., \& Santosa, A. B. (2018). Pengembangan Media Pembelajaran Poster pada Mata Pelajaran Sensor dan Aktuator Kelas XI TEI SMK Negeri 1 Labang Bangkalan. Jurnal Pendidikan Teknik Elektro, 169.

Djamarah, B., \& dkk. (2006). Strategi Belajar Mengajar. Jakarta: PT Rineka Cipta.

Falahudin, I. (2014). Pemanfaatan Media dalam Pembelajaran. Jurnal Lingkar Widyaiswara, 1.

Indonesia, R. (2003). Undang - Undang Nomor 20 mengenai Sistem Pendidikan Nasional.

Kebudayaan, M. P. (2012). Peraturan Menteri Pendidikan dan Kebudayaan Nomor 24 tentang Penyelenggaraan Pendidikan Jarak Jauh .

Kusumawardani, N., Siswanto, J., \& Purnamasari, V. (2018). Pengaruh Model Pembelajaran Kooperatif Tipe STAD Berbantuan Media Poster terhadap Hasil Belajar Peserta Didik. Jurnal Ilmiah Sekolah Dasar, 172-174.

Maulidyawati, D., \& Irham, M. (2020). Penerapan Problem Driven Iterative Adaptation (PDIA) untuk Mengatasi Kesulitan Belajar Matematika Siswa SDN 2 Pungkit. Media Pendidikan Matematika Program Studi Pendidikan Matematika FSTT UNDIKMA , 80-84.

Netriwati, \& Lena, M. S. (2017). Media Pembelajaran Matematika. Lampung: Permata Net.

Purnomo, E. A., Dalyono, B., \& Handayani, S. (2018). Pengembangan Media Pembelajaran Berbasis Android Pada Matakuliah Statistika Pendidikan. Jurnal Karya Pendidkan Matematika Universitas Muhammadiyah Semarang , 118-120.

Rusman, D. K. (2011). Pembelajaran Berbasis Teknologi Informasi dan Komunikasi Profesi Guru. Depok: Rajagrafindo Persada.

Sadirman, A. S., \& dkk. (1996). Media Pendidikan. Jakarta : PT Raja Grafmdo.

Sugiyono. (2015). Metode Penelitian Kuantitatif Kualitatif dan R\&D. Bandung: Alfabeta.

Union, I. M. (t.thn.). IDM 314. Dipetik Januari 12, 2021, dari https://www.idm314.org/ 